\title{
Basic rocks of the inner Fiskefjord area, southern West Greenland
}

\author{
Hans-Jørgen Bengaard
}

During mapping for the Fiskefjord map sheet (64 V.1 $\mathrm{N}-1: 100000)$ observations were made on the basic rocks. Earlier reports on the mapping of the Fiskefjord area have been given by Garde $(1984,1986)$ and Garde et al. (1987), and the reader is referred to these for more detailed descriptions of the general geology.

Most of the inner Fiskefjord area is made up of a variety of gneisses, correlated with the late Archaean Nûk gneisses. The most common type is a weakly banded, tonalitic gneiss, usually grey, sometimes with a lilac tint. Metagranites and more mafic gneisses of dioritic to quartz dioritic composition form mappable units as well as bands of inclusions in the tonalitic gneisses. The gneisses show intrusive relationships to a group of basic and ultrabasic rocks, mainly two-pyroxene basic granulites (named 'pyribolites' by Berthelsen, 1960) with minor dunite and norite. Small amounts of metasedimentary gneiss are associated with the norite.

Most of the gneisses have an amphibolite facies mineralogy, but with disequilibrium textures; these are thought to have arisen during retrogression from earlier granulite facies textures and mineralogy (Garde, in press). Unretrogressed patches, generally on a $10 \mathrm{~m}$ scale retaining granulite facies textures and minerals, are widespread in the gneisses; in contrast, the basic rocks are only locally retrogressed.

The gneisses and the basic rocks together underwent several phases of deformation. In the whole Fiskefjord area, three phases of folding followed by a phase of doming, have been recognised (Garde et al., 1987); in the inner Fiskefjord area, two folding phases were distinguished. The last of these produced open to tight folds with steep, $\mathrm{N}-\mathrm{S}$ trending axial planes, and variably plunging axes.

\section{Norite and metasedimentary gneiss}

The norite is a light grey, generally granular rock, rather friable and weathering to a white gravel, making it easily distinguishable in the field. It occurs mainly as a sheet within some of the pyribolites; the largest sheet has a maximum thickness of $150 \mathrm{~m}$, though 10 to $50 \mathrm{~m}$ is more common, and it can be traced along the bottom of a pyribolite horizon for at least $15 \mathrm{~km}$. In the central parts of thick sheets, the norite consists mainly of plagioclase and brown orthopyroxene (hypersthene), and is massive or weakly lineated. Towards the borders, amphibole replaces hypersthene and a prominent foliation may develop.

The norite is mostly homogeneous; at one locality hypersthene-rich layers were found, several metres thick. They are interpreted as an original igneous layering. Inclusions of ultrabasic rock are frequently found within the norite.

The norite often occurs together with garnet-bearing gneisses, interpreted as metasediments. They are rusty and friable, and appear deeply weathered in outcrop; besides garnet, they consist of varying amounts of quartz, plagioclase and biotite. Cordierite and sillimanite have not been seen in place; cordierite has been

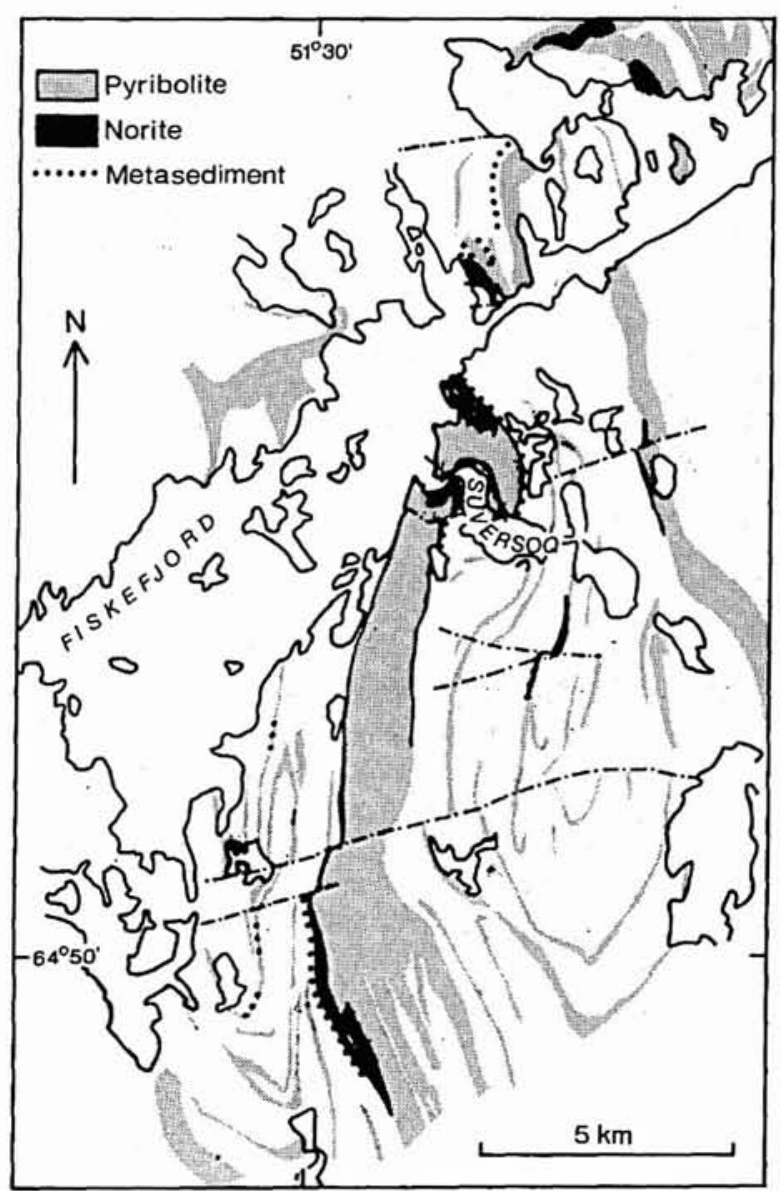

Fig. 1. Simplified map showing the distribution of pyribolite, norite and metasedimentary gneiss in the inner Fiskefjord area. 

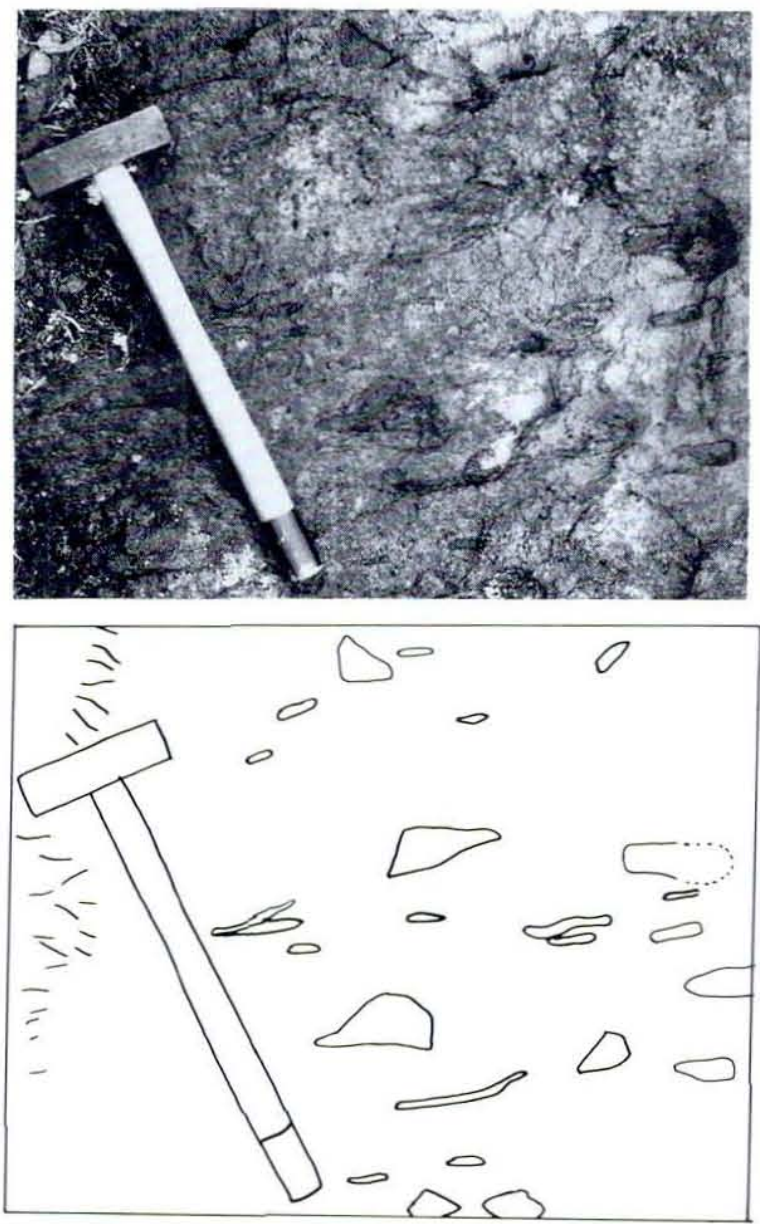

Fig. 2. Conglomeratic structure in pyribolite. Location: $2 \mathrm{~km}$ SSW of the mouth of Suversoq.

found in a loose block, probably from a nearby outcrop.

A compositional banding is generally present in the garnet-bearing gneisses. At one locality, this was seen to be cut by norite; the norite was undeformed along the contact, indicating that it had intruded the metasedimentary gneiss.

The norite - metasedimentary gneiss association is found in several of the pyribolites in the inner Fiskefjord area (fig. 1), and may eventually prove a useful marker horizon in the structural analysis of the area.

\section{A conglomerate in the pyribolitic rocks}

The pyribolites in the inner Fiskefjord area are generally rather homogeneous and structureless showing only an indistinct compositional banding; only in the large pyribolite at the mouth of Suversoq (fig. 1) are more variable types found. Here a $10-20 \mathrm{~m}$ thick horizon, with transitional boundaries to the surrounding homogeneous pyribolites, is rich in olivine and contains scattered millimetre-thick streaks of orthopyroxene. This horizon is situated $50-150 \mathrm{~m}$ above a large sheet of norite, associated with metasediment. Calc-silicate streaks occur in the surrounding pyribolite, testifying to its supracrustal origin.

At one locality the banded horizon exhibits a conglomeratic structure containing clasts of pyribolite. The clasts are mostly angular to subangular, oblong in section, up to $15 \mathrm{~cm}$ long and well separated by the surrounding matrix (fig. 2). They are bordered by a dark, $2-5 \mathrm{~mm}$ thick rim of orthopyroxene. The oblong clasts are parallel to the boundaries of the horizon. The clasts are completely recrystallised under granulite facies conditions, but appear to be undeformed.

If the whole conglomerate is indeed relatively undeformed, then the shape and orientation of its clasts suggest that it is a resedimented conglomerate, probably originating in an unstable, volcanic environment. However, the possibility of a flattened agglomerate or pillow breccia cannot be excluded.

\section{References}

Berthelsen, A. 1960: Structural studies in the pre-Cambrian of western Greenland. II. Geology of Tovqussap nunâ. Bull. Gronlands geol. Unders. 25 (also Meddr Gronland 123,1) 223 pp.

Garde, A. A. 1984: Field work between Fiskefjord and Godthåbsfjord. southern West Greenland. Rapp. Gronlands geol. Unders. 120, 45-50.

Garde, A. A. 1986: Field observations around northern Godthåbsfjord. southern West Greenland. Rapp. Grønlands geol. Unders. 130, 63-68.

Garde, A. A. in press: Retrogression and fluid movement across a granulite-amphibolite facies boundary in middle Archaean Nûk gneisses, Fiskefjord, West Greenland. In Bridgwater, D. (edit.) Fluid transport and the composition of the deep crust. Dordrecht: Reidel.

Garde, A. A., Jensen, S. B. \& Marker, M. 1987: Field work in 1986 in the Fiskefjord area, southern West Greenland. Rapp. Gronlands geol. Unders. 135, 36-42. 